\title{
The ecological role of native and introduced species in the diet of the puma Puma concolor in southern Patagonia
}

\author{
Juan Ignacio Zanón Martínez, Alejandro Travaini, Sonia Zapata \\ Diego Procopio and Miguel Ángel Santillán
}

\begin{abstract}
There is evidence for the ecological extinction of the native prey of the puma Puma concolor in northwestern Argentine Patagonia. In this study we examine whether this is also the case in southern Patagonia. From 2004 to 2007 we examined the puma's diet in three protected areas and two sheep ranches in Santa Cruz province. A total of 282 puma scats were analysed. In two of the protected areas and in the ranches $60-74 \%$ of the puma's diet was native prey. Prey species were primarily guanaco Lama guanicoe, followed by Patagonian mara Dolichotis patagonum, lesser rhea Pterocnemia pennata pennata, Patagonian pichi Zaedyus pichiy and Magellanic penguin Spheniscus magellanicus. In the third protected area the main prey was the European hare Lepus europaeus. Our results show a clear difference in the diet of the puma in southern compared to north-western Patagonia. Large native herbivores (i.e. guanaco and lesser rhea) maintain their role as the main prey species for the puma in southern Patagonia. We suggest, therefore, that native prey could be restored to those areas of Argentine Patagonia, such as the north-west, where they are currently ecologically extinct. Facilitating native species recovery and/or restoration and applying more rigorous controls to prevent the introduction of potential alien prey species of the puma, both within and outside protected areas, needs to be evaluated as a regional strategy.
\end{abstract}

Keywords Argentina, diet, ecological extinction, Patagonia, predation, Puma concolor

JuAn Ignacio Zanón Martínez* (Corresponding author) and Sonia ZAPATA Centro de Investigaciones de Puerto Deseado, Universidad Nacional de la Patagonia Austral, C.C. 238, Avenida Prefectura Naval S/N, 9050 Puerto Deseado, Santa Cruz, Argentina. E-mail jzanon@conicet.gov.ar

Alejandro Travaini and Diego Procopio Centro de Investigaciones de Puerto Deseado, Universidad Nacional de la Patagonia Austral, Consejo Nacional de Investigaciones Científicas y Técnicas, Puerto Deseado, Santa Cruz, Argentina

Miguel Ángel Santillán Centro para el Estudio y Conservación de las Aves Rapaces en Argentina, Universidad Nacional de La Pampa, Santa Rosa, La Pampa, Argentina

*Also at: Consejo Nacional de Investigaciones Científicas y Técnicas, Centro para el Estudio y Conservación de las Aves Rapaces en Argentina, Universidad Nacional de La Pampa, Santa Rosa, La Pampa, Argentina

Received 21 July 2010. Revision requested 7 October 2010.

Accepted 9 December 2010.

\section{Introduction}

The puma Puma concolor is a generalist predator 1 throughout its wide distribution in the Western Hemisphere (Wilson \& Mittermeier, 2009). Its diet can be affected by the abundance and vulnerability of its prey, habitat characteristics, competition with other carnivores (Currier, 1983; Iriarte et al., 199ob), fluctuations in its native prey populations (Novaro et al., 2000; Polisar et al., 2003) and anthropogenic factors (Fuller \& Sievert, 2001). The varied diet of the puma across its range reflects the diverse habitats it inhabits (Sunquist \& Sunquist, 2002). The puma can satisfy its food requirements by predating on either native or introduced wild and domestic species (Ackerman et al., 1984; Ockenfels, 1994; Wehausen, 1996; Franklin et al., 1999; Novaro et al., 2000; Donadio et al., 2009; Foster et al., 2010) of a wide variety of sizes $(<1-150 \mathrm{~kg}$; Iriarte et al., 1990b). Although categorized as Least Concern on the IUCN Red List because it is a widespread species, the puma is considered to be declining and its conservation presents numerous challenges (Caso et al. 2008).

In North America the puma's diet formerly comprised large prey, especially ungulates (Beck et al., 2005). For example, mule deer Odocoileus hemionus, pronghorn Antilocapra americana and bighorn sheep Ovis canadensis are important components of the puma's diet in the states of Utah, Arizona and California, USA, respectively (Ackerman et al., 1984; Ockenfels, 1994; Wehausen, 1996). In the tropical areas of Central and South America the puma's prey includes a wide range of species and sizes, from ungulates to small mammals such as deer, and marsupials and small and large rodents (Rabinowitz \& Nottingham, 1986; Iriarte et al., 199ob; Scognamillo et al., 2003; Foster et al., 2010). In Chilean Patagonia the diet of the puma is dominated by large-bodied native prey such as the guanaco Lama guanicoe and pudu Pudu pudu but pumas also prey on introduced species such as domestic sheep Ovis aries and European hare Lepus europaeus (Wilson, 1984; Yáñez et al., 1986; Iriarte et al., 199ob; Franklin et al., 1999; Rau \& Jiménez, 2002).

There are few studies of the puma's diet in Argentine Patagonia. Studies during 1984-1997 at Lihuel Calel National Park in southern La Pampa province showed that puma diet comprised mainly plains vizcacha Lagostomus maximus, a rodent weighing c. $4.5 \mathrm{~kg}$ (Branch et al., 1996; 
Pessino et al., 2001). During 1985-1994 the populations of the plains vizcacha in the park declined by $>90 \%$ (Branch et al., 1996), and its occurrence as a prey item was reduced by $70 \%$ in the puma diet (Pessino et al., 2001). Over the same period an increase in the consumption of bigger prey (the introduced wild boar Sus scrofa and red deer Cervus elaphus, and guanaco and smaller prey such as the big hairy armadillo Chaetophractus villosus and rodents) was observed (Branch et al., 1996; Pessino et al., 2001). A study in north-western Argentine Patagonia showed that most of the biomass consumed by pumas was of introduced species, particularly the European hare and the red deer, and only a small proportion was of native species, such as the big hairy armadillo and rodents (Novaro et al., 2000). The elevated consumption of introduced prey was the result of their higher abundance and availability compared to that of native prey (Novaro et al., 2000). Such an imbalance can increase until native prey do not interact significantly with their natural predators and are therefore considered ecologically extinct (Estes et al., 1989).

This concept is relevant for the conservation of extant communities because the loss of a species or its functional role may substantially affect the abundance and population structure of other species in the community. For example, guanacos may have suffered local and ecological extinctions throughout Patagonia (Novaro et al., 2000; Pessino et al., 2001) because of human activities such as poaching and livestock husbandry, which has displaced the guanaco towards less favourable foraging areas (Baldi et al., 2001; Travaini et al., 2007). Additionally, agriculture, oil exploitation and mining have altered habitats and made new areas accessible to sport hunters and poachers (Donadio \& Buskirk, 2006), which could have accelerated the decline of native wildlife, both in density (Yáñez et al., 1986; Puig et al., 1997) and distribution (Pedrana et al., 2009).

With the exception of the study of Novaro et al. (2000), in Argentine Patagonia the effect of introduced species on the diet of the puma has not been described. Based on their localized observations Novaro et al. (2000) concluded that the role of the guanaco and lesser rhea Pterocnemia pennata as prey for the puma had been supplanted by red deer, European hare and livestock (sheep, goats and horses), and they suggested that this may also be the case throughout this extensive and heterogeneous region.

The purpose of our study was to examine the supposed ecological extinction of the puma's native prey in southern Patagonia and to determine if the observations of Novaro et al. (2000) could be extrapolated to all of Argentine Patagonia. We analysed puma diet in three protected areas and two sheep ranches in Santa Cruz province. As far as we are aware this is the first study to describe the puma's diet in the largest (c. $250,000 \mathrm{~km}^{2}$ ) and southernmost continental province of Argentine Patagonia.

\section{Study area}

Phytogeographically the study area is in the Central Patagonian District in the Patagonian province, where the characteristic vegetation is a mixed steppe of grassland and shrubs (Cabrera, 1976). The climate is dry and cold, with strong western winds (Harris, 1998); mean annual temperature is $17{ }^{\circ} \mathrm{C}$ and mean annual precipitation varies from $125 \mathrm{~mm}$ in the east to $500 \mathrm{~mm}$ in the west. Our study was conducted in three protected areas and two sheep ranches in Santa Cruz province (Fig. 1). The protected areas, which are under the Argentine National Park Administration, were the $570-\mathrm{km}^{2}$ Monumento Natural Bosques Petrificados, the $1,150-\mathrm{km}^{2}$ Perito Moreno National Park and the $610-\mathrm{km}^{2}$ Monte León National Park; the latter was created in 2000 from a sheep ranch. The sheep ranches were the $400-\mathrm{km}^{2} 25$ de Marzo Ranch, $>100 \mathrm{~km}$ from the nearest protected area, the Monumento Natural Bosques Petrificados, and the $200-\mathrm{km}^{2}$ Doraike Ranch neighbouring Monte León National Park. The Monumento Natural Bosques Petrificados and the 25 de Marzo Ranch are on the central plateau of Santa Cruz, where shrub-steppe is the dominant vegetation type. The Perito Moreno National Park is in the west of the province, where the Andean mountain range and the Patagonian steppe are the main vegetation types. The Monte León National Park and the Doraike Ranch are in the south-east, on the Atlantic coast, where the dominant vegetation type is shrub-steppe.

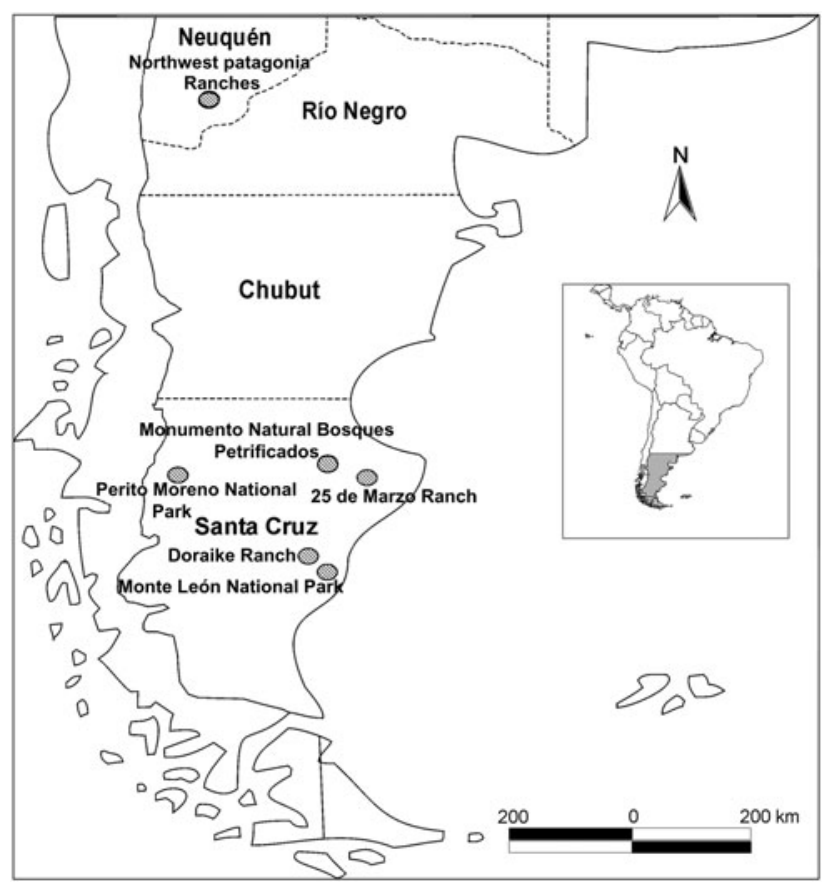

Fig. 1 Location of the five study sites in Santa Cruz province and the ranches in north-west Patagonia studied by Novaro et al. (2000). The inset shows the location of the main map in South America. 


\section{Methods}

Puma diet was determined by identification and quantification of prey remains in 282 scats, which were collected in the five study sites during 2004-2007. At Monumento Natural Bosques Petrificados puma scats were collected annually by searching within $4-\mathrm{km}^{2}$ randomly selected plots whilst developing a carnivore monitoring programme based on signs (Travaini et al., 2003). At the other four sites scats were collected specifically for this study by walking through the area, selecting the most rugged sites where puma scats are easily found.

Puma scats were identified by their size, colour and shape (Yáñez et al., 1986). They are easily differentiated from those of culpeo Lycalopex culpaeus and grey foxes Lycalopex griseus (Zapata et al., 2005). The area is also inhabited by the pampas cat Leopardus colocolo and Geoffroy's cat Leopardus geoffroyi. These scats are easily differentiated because of their smaller size and location, as the two species usually make their latrines in small caves and crooks of trees where a puma could not reach (Sunquist \& Sunquist, 2002; Zapata et al., 2005). Collected scats were dried and stored in labelled paper envelopes until analysis.
Bones and hairs of mammalian prey were identified using a reference collection and a key of skulls and jaws (Pearson, 1995), or patterns of hair scales and medulla (Chehébar \& Martín, 1989). Bird remains, feathers, and bones were identified by comparing them with our own reference material. Identified prey items were grouped into taxa. Puma diet composition at each site was expressed as percentage occurrence (i.e. the number of times that an item appears in all scats expressed as the percentage of the total number of scats) and relative biomass of prey consumed using the equation of Ackerman et al. (1984). Prey body masses were obtained from Redford \& Eisenberg (1992) and from our own records.

\section{Results}

In the five areas studied the puma preyed on at least 14 mammal and four bird species (Table 1). In the Monumento Natural Bosques Petrificados the main prey of the puma according to consumed biomass was the guanaco, followed by the European hare, the Patagonian pichi Zaedyus pichiy, and lesser rheas, although European hare was the most common prey, followed by the guanaco

Table 1 Diet of the puma Puma concolor in the five study sties in Argentine Patagonia (Fig. 1) during 2004-2007 as \% occurrence and \% consumed biomass (see text for details). Percentages of occurrences do not sum to 100 because diets are expressed as the $\%$ of total number of scats.

\begin{tabular}{|c|c|c|c|c|c|c|c|c|c|c|}
\hline \multirow[b]{2}{*}{ Prey species } & \multicolumn{2}{|c|}{$\begin{array}{l}\text { Monumento Natural } \\
\text { Bosques Petrificados }\end{array}$} & \multicolumn{2}{|c|}{$\begin{array}{l}\text { Perito Moreno } \\
\text { National Park }\end{array}$} & \multicolumn{2}{|c|}{$\begin{array}{l}\text { Monte León } \\
\text { National Park }\end{array}$} & \multicolumn{2}{|c|}{$\begin{array}{l}25 \text { de Marzo } \\
\text { Ranch }\end{array}$} & \multicolumn{2}{|c|}{ Doraike Ranch } \\
\hline & $\begin{array}{l}\% \\
\text { occurrence }\end{array}$ & $\begin{array}{l}\% \\
\text { biomass }\end{array}$ & $\begin{array}{l}\% \\
\text { occurrence }\end{array}$ & $\begin{array}{l}\% \\
\text { biomass }\end{array}$ & $\begin{array}{l}\% \\
\text { occurrence }\end{array}$ & $\begin{array}{l}\% \\
\text { biomass }\end{array}$ & $\begin{array}{l}\% \\
\text { occurrence }\end{array}$ & $\begin{array}{l}\% \\
\text { biomass }\end{array}$ & $\begin{array}{l}\% \\
\text { occurrence }\end{array}$ & $\begin{array}{l}\% \\
\text { biomass }\end{array}$ \\
\hline Guanaco Lama guanicoe & 45.7 & 58.6 & 13.3 & 23.2 & 25.5 & 36.5 & 33.3 & 49.8 & 50.0 & 68.8 \\
\hline $\begin{array}{l}\text { Patagonian mara } \\
\text { Dolichotis patagonum }\end{array}$ & & & & & & & 22.2 & 16.7 & & \\
\hline $\begin{array}{l}\text { Big hairy armadillo } \\
\text { Chaetophractus villosus }\end{array}$ & 0.5 & 0.3 & & & & & & & & \\
\hline $\begin{array}{l}\text { Patagonian pichi Zaedyus } \\
\text { pichiy }\end{array}$ & 14.5 & 5.1 & & & & & 11.1 & 4.5 & & \\
\hline Rodents $^{1}$ & 11.8 & 0.1 & & & 3.6 & 0.0 & & & 3.6 & 0.0 \\
\hline Other mammals ${ }^{2}$ & 16.1 & 1.8 & 6.7 & 0.4 & 3.6 & 0.2 & 5.6 & 3.5 & 12.5 & 0.6 \\
\hline $\begin{array}{l}\text { Lesser rhea Pterocnemia } \\
\text { pennata }\end{array}$ & 6.5 & 3.9 & & & & & & & & \\
\hline $\begin{array}{l}\text { Magellanic penguin } \\
\text { Spheniscus magellanicus }\end{array}$ & & & & & 38.2 & 24.3 & & & & \\
\hline $\begin{array}{l}\text { Native mammals \& birds } \\
\quad \text { (subtotal) }\end{array}$ & 95.1 & 69.8 & 20.0 & 23.6 & 70.9 & 61.0 & 72.2 & 74.5 & 66.1 & 69.4 \\
\hline Other birds ${ }^{3}$ & 8.6 & 0.6 & & & 5.4 & 0.2 & & & & \\
\hline $\begin{array}{l}\text { European hare Lepus } \\
\text { europaeus }\end{array}$ & 52.7 & 29.6 & 100 & 76.4 & 61.8 & 38.8 & 38.9 & 25.5 & 50.0 & 30.2 \\
\hline No. of prey items & 292 & & 18 & & 76 & & 21 & & 11 & \\
\hline No. of scats & 186 & & 15 & & 55 & & 18 & & 8 & \\
\hline
\end{tabular}

${ }^{1}$ Includes Ctenomys magellanicus, Eligmodontia morgani, Phyllotis xanthophygus, Abrotrix xanthorinus, Graomys grisoflaveus, Microcavia australis and Reithrodon auritus

${ }^{2}$ Includes Mustelidae Galictis cuja and the marsupial Lestodelphys halli

${ }^{3}$ Includes unidentified birds, Cloephaga picta and Tinamotis ingoufi 
and other mammals (mainly rodents). Similarly, puma diet at the 25 de Marzo Ranch comprised guanaco, followed by the European hare, and another native mammal, the Patagonian mara Dolichotis patagonum.

In Monte León and Perito Moreno National Parks the main prey of the puma according to consumed biomass was the European hare. The second most important prey item in these National Parks was the guanaco. The Magellanic penguin Spheniscus magellanicus, never previously described in the puma diet, was consumed in Monte León National Park. In the Doraike Ranch, which neighbours Monte León National Park, the main prey was the guanaco, followed by the European hare.

Native prey contributed $>60 \%$ of the total consumed biomass in the Monumento Natural Bosques Petrificados, Monte León National Park and their neighbouring ranches (25 de Marzo Ranch, and Doraike Ranch; Fig. 2). Native prey in Perito Moreno National Park represented only $23.6 \%$ of the consumed biomass and the introduced European hare dominated its diet, accounting for the $76.4 \%$ of the total consumed biomass (Fig. 2).

\section{Discussion}

In Santa Cruz province native prey species are still part of the diet of the puma. The majority of scats collected indicated that the puma's diet there includes guanaco and variable contributions of Patagonian mara, Patagonian pichi and the Magellanic penguin. Nevertheless, the introduced European hare was also an important component and found in scats from all five sites. Since its introduction in Argentina and Chile (Grigera \& Rapoport, 1983) the European hare has been heavily consumed by both terrestrial and aerial predators (Iriarte et al., 1990a,b; Rau \& Jiménez, 2002; Zapata et al., 2005). In some areas of
Argentine Patagonia the European hare has become the base for the formation of new trophic guilds (Zapata et al., 2007) by displacing native prey from their ecological role (Lamberttucci et al., 2009; Walker \& Novaro, 2009). This phenomenon has been attributed to the hare's extensive distribution, high abundance and optimal size as prey for many native predators (Donadio et al., 2005). In Perito Moreno National Park the European hare was the main component of puma scats. This protected area includes the ecotone between the Andean mountain range and the Patagonian steppe, where suitable habitat results in high densities of hares (Park Rangers, pers. comm.).

A study in Torres del Paine National Park in Chilean Patagonia found a density of 11.7 guanacos per $\mathrm{km}^{2}$ (Franklin et al., 1999), more than twice that found in our study area (4.7 per $\mathrm{km}^{2}$; E. Daer, National Park Administration, pers. comm.) but guanacos constituted the most important prey item in Santa Cruz province, comprising $50 \%$ or more of puma diet in the two sheep ranches and Monumento Natural Bosques Petrificados, and 59\% of consumed biomass in Torres del Paine National Park. In north-western Patagonia the guanaco occurs at a density of only 0.67 individuals per $\mathrm{km}^{2}$ and Novaro et al. (2000) did not detect the species in the diet of the puma.

Among the other native mammals in the puma's diet in Santa Cruz province edentates, present in the diet in Monumento Natural Bosques Petrificados, are a frequent puma prey item in other areas of Patagonia (Branch et al., 1996; Novaro et al., 2000; Pessino et al., 2001). The Patagonian mara is an uncommon item in the diet of pumas; it was found only in puma scats from the 25 de Marzo Ranch, which is at the southern limit of the distribution of the Patagonian Mara (Redford \& Eisenberg, 1992). To our knowledge this is the first study to report its presence in the diet of the puma in an unprotected area.

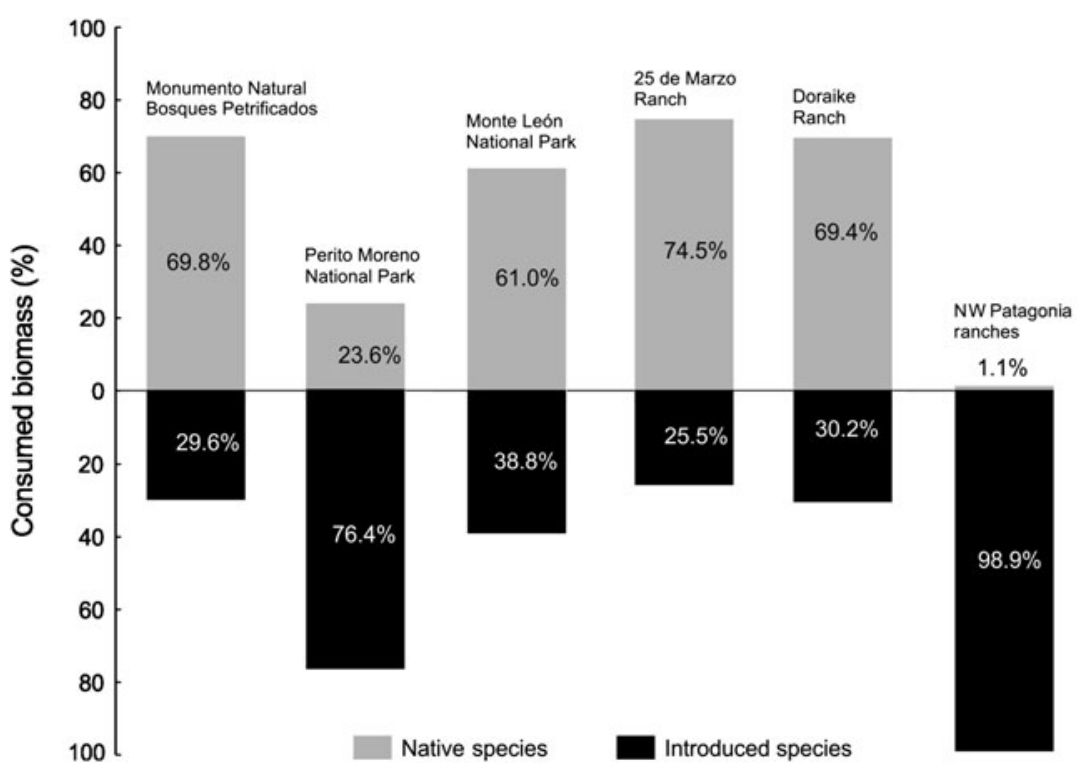

FIG. 2 Percentage of biomass of native and introduced species consumed by the puma Puma concolor at the five study sites and the ranches in north-west Patagonia, the latter from Novaro et al. (2000; Fig. 1). 
The contribution of rodent biomass to the puma diet in Santa Cruz was similar to that in north-western Patagonia (Novaro et al., 2000) but much less than in Central America, where rodents are the main prey item of the puma (Iriarte et al., 1990a). This difference is probably due to the lack of larger prey in Central America, or because of trophic competition with the jaguar Panthera onca (Scognamillo et al., 2003).

Both the Magellanic penguin, in Monte León National Park, and the lesser rhea, in Monumento Natural Bosques Petrificados, were prominent in the puma's diet. The Magellanic penguin is a newly recorded prey item for the puma. At Monte León National Park, Magellanic penguins nest under bushes, or dig burrows, throughout spring and summer (September-April; Schiavini et al., 2005). The penguin can be a valuable prey for the puma not only because of its body mass (3.65 kg; Gandini et al., 1992) but also because of its abundance and predictability at the colonies. The second most consumed bird species, the lesser rhea, is distributed across the entire Santa Cruz province (Travaini et al., 2007). This species was also consumed by pumas in Chile in Torres del Paine National Park but at a low frequency (Franklin et al., 1999).

Our results show that native prey, particularly guanacos, are the most important prey for pumas in southern Patagonia, both in protected and unprotected areas, thus showing that native species are still performing an ecological function as prey for pumas. Our results do not support the suggestion of Novaro et al. (2000) that native prey no longer have an ecological role as prey of the puma in Argentine Patagonia, at least in Santa Cruz province. Many sheep ranches in north and central Santa Cruz province were abandoned during 1991-2003 because of a combination of economic and climatic factors (Travaini et al., 2000) and this could have led to a resurgence of native prey. We suggest, therefore, that native prey could be restored to those areas of Argentine Patagonia, such as the north-west, where they are currently ecologically extinct. Facilitating native species recovery and/ or restoration and applying more rigorous controls to prevent the introduction of potential alien prey species of the puma both, within and outside protected areas, needs to be evaluated as a regional strategy.

\section{Acknowledgements}

Funds were provided by the Universidad Nacional de la Patagonia Austral, Universidad Nacional de La Pampa, project PI29/B099 and the BBVA Foundation through a grant under the Conservation Biology Program. We acknowledge the support and permits provided by the National Parks Administration of Argentina and the ranch owners. During the writing of this article JIZM was supported by a Conservation, Research and Education Opportunities fellowship programme and Consejo Nacional de Investigaciones Científicas y Técnicas predoctoral fellowship. C. Zoratti, L. Montenegro, G. Soria, F. Escobar, G. Aguilera, P. Collavino, E. Daher, M. Yaya and M. Bronfman collaborated in the fieldwork. We also thank J.B. Mesa, J. Feaga and an anonymous reviewer for help and comments.

\section{References}

Ackerman, B.B., Lindzey, F.G. \& Hemker, T.P. (1984) Cougar food habits in southern Utah. The Journal of Wildlife Management, 48, 147-145.

Baldi, R., Albon, S.D. \& Elston, D.A. (2001) Guanacos and sheep: evidence for continuing competition in arid Patagonia. Oecologia, 129, 561-570.

Beck, T., Beecham, J., Beier, P., Hofstra, T., Hornocker, M., LindeZey, F. et al. (2005) Cougar Management Guidelines. WildFutures, Washington, DC, USA.

Branch, L.C., Pessino, M. \& Villareal, D. (1996) Response of pumas to a population decline of the plains vizcacha. Journal of Mammalogy, 77, 1132-1140.

CABrerA, A.L. (1976) Regiones fitogeográficas argentinas. ACME, Buenos Aires, Argentina.

Caso, A., Lopez-Gonzalez, C., Payan, E., Eizirik, E., De Oliveira, T., Leitepitman, R. et al. (2008) Puma concolor. In IUCN Red List of Threatened Species v. 2011.1. Http://www.iucnredlist.org [accessed 23 June 2011].

Chenébar, C. \& Martín, S. (1989) Guía para el reconocimiento microscópico de los pelos de los mamíferos de la Patagonia. Doñana Acta Vertebrata, 19, 247-292.

Currier, M.J.P. (1983) Felis concolor. Mammalian Species, 200, 1-7. Donadio, E. \& Buskirk, S.W. (2006) Flight behavior in guanacos and vicuñas in areas with and without poaching in western Argentina. Biological Conservation, 127, 139-145.

Donadio, E., Novaro, A.J., Buskirk, S.W., Wurstten, A., Vitali, M.S. \& Monteverde, M.J. (2009) Evaluating a potentially strong trophic interaction: pumas and wild camelids in protected areas of Argentina. Journal of Zoology, 280, 33-40.

Donadio, E., Pauli, J.N. \& Bonino, N.A. (2005) A method to estimate body mass and relative age of exotic lagomorphs in the southern Neotropics. Acta Theriologica, 50, 81-89.

Estes, J.A., DugGins, D.O. \& Rathiun, G.B. (1989) The ecology of extinctions in kelp forest communities. Conservation Biology, 3 , $252-264$

Foster, R.J., Harmsen, B.J., Valdes, B., Pomilla, C. \& DonCASTER, C.P. (2010) Food habits of sympatric jaguars and pumas across a gradient of human disturbance. Journal of Zoology, 280, 309-318.

Franklin, W.L., Johnson, W.E., Sarno, R.J. \& Iriarte, J.A. (1999) Ecology of the Patagonia puma Felis concolor patagonica in southern Chile. Biological Conservation, 90, 33-40.

Fuller, T.K. \& Sievert, P.R. (2001) Carnivore demography and the consequences of changes in prey availability. In Carnivore Conservation (eds J.L. Gittleman, S.M. Funk, D.W. Macdonald \& R.K. Wayne), pp. 163-177. Cambridge University Press, Cambridge, UK.

Gandini, P., Frere, E. \& Holik, T. (1992) Implicancias de las diferencias en el tamaño corporal entre colonias para el uso de medidas morfométricas como método de sexado en Spheniscus magellanicus. Hornero, 13, 211-213.

Grigera, D.E. \& Rapoport, E.H. (1983) Status and distribution of the European hare in South America. Journal of Mammalogy, $64,163-166$. 
HARris, G. (1998) A Guide to the Birds and Mammals of Coastal Patagonia. Princeton University Press, Princeton, USA.

Iriarte, J.A., Franklin, W.L. \& Johnson, W.E. (1990a) Diets of sympatric raptors in southern Chile. Journal of Raptor Research, 24, 41-46.

Iriarte, J.A., Franklin, W.L., Johnson, W.E. \& Redford, K.H. (1990b) Biogeographic variation of food habits and body size of the America puma. Oecologia, 85, 185-190.

Krebs, C.J. (1999) Ecological Methodology. 2nd edition. Benjamin Cummings, Menlo Park, USA.

Lamberttucci, S.A., Trejo, A., Di Martino, S., SanchezZapata, J.A., Donazar, J.A. \& Hiraldo, F. (2009) Spatial and temporal patterns in the diet of the Andean condor: ecological replacement of native fauna by exotic species. Animal Conservation, 12, 338-345.

Manly, B.F.J. (1994) Multivariate Statistical Methods. A Primer. Chapman \& Hall, London, UK.

Novaro, A.J., Funes, M.C. \& Walker, R.S. (2000) Ecological extinction of native prey of a carnivore assemblage in Argentine Patagonia. Biological Conservation, 92, 25-33.

OCKENFELS, R.A. (1994) Mountain lion predation on pronghorn in Central Arizona. The Southwestern Naturalist, 39, 305-306.

Pearson, O.P. (1995) Annotated keys for identifying small mammals living in or near Nahuel Huapi National Park or Lanín National Park, southern Argentina. Mastozoología Neotropical, 2, 99-148.

Pedrana, J., Rodríguez, A., Bustamante, J., Travaini, A. \& Zanón Martínez, J.I. (2009) Failure to estimate reliable sex ratios of guanaco from road-survey data. Canadian Journal of Zoology, 87, 886-894.

Pessino, M.E.M., Sarasola, J.H., Wander, C. \& Besoky, N. (2001) Respuesta a largo plazo del puma (Puma concolor) a una declinación poblacional de la vizcacha (Lagostomus maximus) en el desierto del Monte, Argentina. Ecología Austral, 11, 61-67.

Polisar, J., Maxit, I.E., Scognamillo, D., Farrell, L., Sunquist, M. \& EinseberG, J.F. (2003) Jaguars, pumas, their prey base, and cattle ranching: ecological interpretation of a management problem. Biological Conservation, 109, 297-310.

Puig, S., Videla, F. \& Cona, M.I. (1997) Diet and abundance of the guanaco (Lama guanicoe Müller 1776) in four habitats of northern Patagonia, Argentina. Journal of Arid Environments, 36, 343-357.

Rabinowitz, A. \& Nottingham, B. (1986) Ecology and behaviour of the jaguar (Panthera onca) in Belize, Central America. Journal of Zoology, 210, 149-159.

RAU, J.R. \& JimÉneZ, J.E. (2002) Diet of puma (Puma concolor, Carnivora: Felidae) in coastal and Andean ranges of southern Chile. Studies on Neotropical Fauna and Environment, 37, 1-5.

Redford, K.H. \& EisenberG, J.F. (1992) Mammals of the Neotropics: The Southern Cone Volume 2: Chile, Argentina, Uruguay, Paraguay. University of Chicago Press, Chicago, USA.

Schiavini, A., Yorio, P., Gandini, P., Raya Rey, A. \& Boersma, P.D. (2005) Los pingüinos de las costas argentinas: estado poblacional y conservación. Hornero, 20, 5-23.

Scognamillo, D., Maxit, I.E., Sunquist, M. \& Polisar, J. (2003) Coexistencia de jaguar (Panthera onca) and puma (Puma concolor) in a mosaic landscape in the Venezuelen llanos. Journal of Zoology, 259, 269-279.

Sunquist, M. \& Sunquist, F. (2002) Wild Cats of the World. The University of Chicago Press, Chicago, USA.

Travaini, A., Bustamante, J., Rodriguez, A., Zapata, S., Procopio, D., Pedrana, J. \& Peck, R.M. (2007) An integrated framework to map animal distributions in large and remote regions. Diversity and Distributions, 13, 289-298.

Travaini, A., Pereira, J., Martínez-Peck, R. \& Zapata, C.S. (2003) Monitoreo de zorros colorados (Pseudalopex culpaeus) y grises (Pseudalopex griseus) en Patagonia: diseño y comparación de métodos alternativos. Mastozoología Neotropical, 10, 277-291.

Travaini, A., Zapata, C.S., Martínez-Peck, R. \& Delibes, M. (2000) Percepción y actitud humanas hacia la predación de ganado ovino por el zorro colorado (Pseudolopex culpaeus) en Santa Cruz. Mastozoología Neotropical, 7, 117-129.

W Alker, S. \& Novaro, A. (2009) The world's southernmost pumas in Patagonia and the southern Andes. In Cougar: Ecology and Conservation (eds M. Hornocker, S. Negri \& A. Rabinowitz), pp. 91-99. University of Chicago Press, Chicago, USA.

WEHAUSEN, J.D. (1996) Effects of mountain lion predation on bighorn sheep in the Sierra Nevada and Granite Mountains of California. Wildlife Society Bulletin, 24, 471-479.

Wilson, P. (1984) Puma predation on guanacos in Torres del Paine National Park, Chile. Mammalia, 48, 1-8.

Wilson, D.E. \& Mittermeier, R.A. (2009) Handbook of the Mammals of the World. Vol. 1. Carnivores. Lynx Edicions, Barcelona, Spain.

Yáñez, J.L., Cárdenas, J.C., Gezelle, P. \& Jaksic, F.M. (1986) Food habits of the southernmost mountain lions (Felis concolor) in South America: natural versus livestocked ranges. Journal of Mammalogy, 67, 604-606.

Zapata, C.S., Travaini, A., Delibes, M. \& Martínez-Peck, R. (2005) Food habits and resource partitioning between grey and culpeo foxes in southeastern Argentine Patagonia. Studies on Neotropical Fauna and Environment, 40, 97-103.

Zapata, S.C., Travaini, A., Ferreras, P. \& Delibes, M. (2007) Analysis of trophic structure of two carnivore assemblages by means of guild identification. European Journal of Wildlife Research, 53, 276-286.

\section{Biographical sketches}

Juan Ignacio Zanón Martínez's research focuses on the ecology and conservation of carnivores in Argentine Patagonia. Alejandro Travaini, Sonia Zapata and Diego Procopio are scientific researchers at the Research Center of Puerto DeseadoNational University of Patagonia Austral. They are working on behavioural ecology and conservation of wildlife in the southernmost continental province of Argentine Patagonia. Miguel Ángel SANTILLÁn carries out research on raptors and passerines in $\mathrm{La}$ Pampa province of Argentina. 